\title{
"Como Deus É Ciente em sua Essência Divina": a Presciência de Deus em Santo Tomás de Aquino E no Livro da Contemplaçấo (C. 1271-1273) DE RAMON LLULL ${ }^{1}$
}

\author{
Ricardo da Costa \\ Sidney Silveira ${ }^{3}$
}

\begin{abstract}
RESUMO: A proposta deste trabalho é analisar a concepção filosófica de presciência em Santo Tomás de Aquino e Ramon Llull, nas obras Suma Teológica e O Livro da Contemplação. Para isso, discorremos previamente sobre o conceito de ciência, base aristotélica tomista. Por fim, apresentamos a tradução (inédita) de um extrato do Livro da Contemplaçâo, como base documental para a segunda parte do trabalho.
\end{abstract}

PALAVRAS-CHAVE: Ciência. Presciência. Filosofia medieval.

\section{CiÊNCIA, Verdade}

2. Sem a verdade não há nada.

3. Se não existisse a verdade, tudo o que existe seria falso.

(Ramon Llull, 2011a, CXI, "Da verdade", 2-3. - tradução nossa).

Antes de tratarmos da presciência divina, devemos definir, mesmo que brevemente, o que é ciência. Temos ciência de algo quando nossa inteligência — de acordo com o seu modo próprio — assimila realidade como ela é. Para Tomás de Aquino (1225-1274), em sentido lato, ciência significa qualquer tipo de conhecimento intelectivo a partir do qual a realidade se faz presente

\footnotetext{
${ }^{1}$ Conferência proferida no dia 20 de maio de 2013 no II Simpósio de Filosofia Patrística e Medieval da Faculdade São Bento de São Paulo.

${ }^{2}$ Professor efetivo (Associado III) do Departamento de Teoria da Arte e Música da Universidade Federal do Espírito Santo (UFES). Acadèmic corresponent a l'estranger da Reial Acadèmia de Bones Lletres de Barcelona. E-mail: ricardo@ricardocosta.com.

${ }^{3}$ Jornalista, Diretor do Instituto Angelicum de Estudos Tomistas (http://www.institutoangelicum.com. br/). E-mail: sidneylsilveira@gmail.com.
} 
à alma racional. ${ }^{4}$ Em sentido estrito, trata-se de um hábito intelectivo, ${ }^{5}$ mais precisamente a segunda virtude noética (sendo a primeira delas a sabedoria dos primeiros princípios da razão especulativa). ${ }^{6}$ Por fim, ciência é também o movimento acidental da potência intelectiva mediante o qual a forma de um objeto específico existe imaterialmente na inteligência humana. ${ }^{7}$

Nesse contexto, como afirma o filósofo italiano Battista Mondin, embora Tomás de Aquino acolha alguns princípios da gnosiologia aristotélica - como, por exemplo, o caráter demonstrativo da ciência humana e a circunstância de ela ser um conhecimento "certo e evidente" — , ele não acolhe in totum a epistemologia do Estagirita pelo fato de que esta é insuficiente para definir de maneira satisfatória o estatuto científico da teologia, ${ }^{8}$ assim como para classificar o modo próprio da ciência angélica, acrescentemos nós. No tópico acima mencionado, Mondin está a aludir à clássica definição tomista entre evidência quoad se e evidência quoad nos.

A ciência, para o que nos interessa apresentar neste breve texto, pressupóe o conceito de verdade como certa adequação da inteligência às coisas como elas

4 "Scientia nihil aliud esse videtur quam descriptio rerum in anima, cum scientia esse dicatur assimilatio scientis ad scitum” (TOMÁS DE AQUINO, Questōes Disputadas, De Veritate, 2013, q. 11, art. 1, ob.11).

5 "Ulterius in eadem via proceditur inquirendo ex istis principiis in conclusiones; et ad hoc perficit alia virtus intellectualis quae dicitur 'scientia”" (TOMÁS DE AQUINO. Suma de Teología, 1953, III Sent, d. 34, q.1, art. 2).

${ }^{6}$ Sobre as três virtudes especulativas, entre as quais se encontra a ciência, Tomás tratou amiúde na Suma de Teología (I-II, q.57): "Et ideo habitus perficiens intellectum ad huiusmodi veri considerationem, vocatur intellectus, qui est habitus principiorum. Verum autem quod est per aliud notum, non statim percipitur ab intellectu, sed per inquisitionem rationis, et se habet in ratione termini. Quod quidem potest esse dupliciter, uno modo, ut sit ultimum in aliquo genere; alio modo, ut sit ultimum respectu totius cognitionis humanae. Et quia ea quae sunt posterius nota quoad nos, sunt priora et magis nota secundum naturam, ut dicitur in I Physic.; ideo id quod est ultimum respectu totius cognitionis humanae, est id quod est primum et maxime cognoscibile secundum naturam. Et circa huiusmodi est sapientia, quae considerat altissimas causas, ut dicitur in I Metaphys. Unde convenienter iudicat et ordinat de omnibus, quia iudicium perfectum et universale haberi non potest nisi per resolutionem ad primas causas. Ad id vero quod est ultimum in hoc vel in illo genere cognoscibilium, perficit intellectum scientia (grifo nosso). Et ideo secundum diversa genera scibilium, sunt diversi habitus scientiarum, cum tamen sapientia non sit nisi una". (AQUINO, Tomás de. Suma de Teología, 1953, IaII, q. 57, art. 2, resp.).

7 "Est ordinata aggregatio ipsarum specierum existentium in intellectu" (TOMÁS DE AQUINO. Suma contra os gentios, 1990 , cap. 56, p. 105).

${ }^{8}$ Ver MONDIN, Battista. Dizionario Enciclopedico del Pensiero di Tommaso d'Aquino. Bologna, Itália: Studio Domenicano, 2000, p. 615. 
são. ${ }^{9}$ No homem, as verdades (mundo do inteligível) são abstraídas das coisas; no anjo, criatura espiritual, essas espécies inteligíveis são infundidas pelo Próprio Ser Subsistente, razão pela qual o conhecimento angélico não é extraído das coisas, mas da sua própria inteligência — criada por Deus já na plena posse dos inteligíveis situados no plano da natureza. ${ }^{10}$ Eis aqui a incomensurável distância entre a ciência humana e a angélica, na doutrina tomista: as coisas compostas de matéria e forma são a fonte da verdade para o homem, que as conhece a partir da abstraçáo de suas notas individuantes radicadas na matéria; em contrapartida, o anjo não abstrai o inteligível pelo simples fato de que já o possui. Seja como for, para que haja a ciência humana ou angélica, é preciso haver uma inteligência que, extraindo das coisas o seu substrato formal, lhes descortine as especificidades e separe o essencial do acidental.

Reiteremos que toda ciência pressupóe certa adequação entre a inteligência e as coisas. No homem, essa adequação ocorre pela abstração que somos capazes de fazer graças à potência intelectiva de que somos dotados. Em síntese, abstraímos as quididades sensíveis e chegamos ao conceito de "número", de "cavalo" etc.; conhecemos as essências e, também, os acidentes que estão nelas. Todavia, o que seria um acidente na metafísica tomista? Neste ponto, convém distinguir três tipos de acidentes, enumerados por Tomás de Aquino em diferentes obras: os que são causados a partir da espécie e se chamam "próprios", como a risibilidade, no homem; os que são inerentes aos individuos

\footnotetext{
${ }^{9}$ A verdade é a adequação entre a inteligência e as coisas, diz Santo Tomás, na esteira do filósofo Isaac Israeli. Mas o que se quer dizer exatamente com isso? Em suma, que a verdade: a) é uma relação ontológica; b) é uma relação categorial; c) pressupóe um ente real extra mentis; d) está primeiramente nas coisas, como fonte; e) está formalmente na inteligência; f) é o objeto formal terminativo dos movimentos da inteligência. Noutras palavras, a verdade na inteligência tem como causa material o ser das coisas. Assim, pode-se perfeitamente sustentar, com a escola tomista, que a verdade se deve considerar em duplo aspecto: transcendental, no ente; e formal, na inteligência. Com relação à verdade transcendental, que náo é outra coisa senáo o ente real mesmo, vale dizer que ela é anterior à verdade no intelecto humano, e posterior à verdade no intelecto divino - que é o seu modelo, a sua causa exemplar. Em suma, o intelecto humano, para laborar, precisa alimentar-se do ser das coisas, que, por sua vez, provém do intelecto divino. Tendo isso em vista, Santo Tomás frisa: "A verdade está propriamente no intelecto, seja humano ou divino, assim como a saúde está no corpo do animal" (TOMÁS DE AQUINO. Questöes Disputadas, De Veritate, I, a. 4). Remetamo-nos agora ao que afirma o Aquinate sobre o conceito de idéia, pois é a propósito do que se afirmou da causa exemplar e do que se dirá abaixo: "O que em grego se chamou idéia, em latim se chama forma; daí que entendamos por idéia a forma das coisas existente fora das coisas mesmas. E a forma de uma coisa existente fora da coisa pode ter duas funçóes: ser modelo (exemplar) daquilo de que é forma; e ser princípio de conhecimento, e assim se diz que a forma do cognoscível está no cognoscente" ('TOMÁS DE AQUINO. Suma de Teología, 1953, I, q. 15, art. 1, resp. - tradução nossa).
}

10 "Ad primum ergo dicendum quod in mente Angeli sunt similitudines creaturarum, non quidem ab ipsis creaturis acceptae, sed a Deo”. (TOMÁS DE AQUINO. Suma de Teología, 1953, I, q. 55, ad. 1). 
e inseparáveis deles, como, por exemplo, "masculino" e "feminino"; e os que são causados pelos indivíduos, porém deles são metafisicamente separáveis, como o sentar-se ou o caminhar. Em todos os casos, o Aquinate frisa que todo e qualquer acidente tem em comum o não pertencer à essência da coisa (est autem commune omni accidenti quod non sit de essentia rei), embora emane dela, direta ou indiretamente. ${ }^{11} \mathrm{O}$ conhecimento está exatamente entre estes últimos tipos de acidente, na medida em que, no homem, entre ser e conhecer não há identidade absoluta, pois entendemos ou não as coisas. Isto significa que, como salientava Aristóteles (384-322 a. C.), a nossa inteligência é tábua rasa na qual, com o decorrer do tempo, colocamos os conceitos que abstraímos da realidade. ${ }^{12}$

Toda ciência humana provém, pois, da realidade das coisas. É filha de uma realidade exterior que passa pela interseçáo de uma potência imaterial interna integrante de sua alma. Neste processo cognoscitivo, pensamos as coisas e retornamos à realidade na forma de conceito imaterial. Isto é a verdade para o homem - e é neste sentido estrito que a adequação entre a nossa inteligência e as coisas se diz hábito mental da verdade, ou virtude operativa da potência intelectiva. Em breves palavras, a ciência humana implica uma realidade que existe para além de nossa mente e não depende dela para ser o que é. ${ }^{13}$ Existe uma realidade real que nossa inteligência consegue entender em sua essência, em seus acidentes, em suas formas etc. Isto se dá no tempo porque, no caso humano, todas as coisas conhecidas estão arrojadas no tempo e têm composição de matéria e forma, substância e acidentes, ato e potência, essência e ser. Daí assinalar Tomás de Aquino que o primeiro contato da inteligência humana é com a essência das coisas materiais (quidditas rei materialis).

Em síntese, a inteligência humana opera no tempo e não esgota a inteligibilidade dos entes; ${ }^{14}$ a inteligência angélica opera no $e v o^{15}$ e esgota

\footnotetext{
11 "Ad septimum dicendum quod tria sunt genera accidentium: quaedam enim causantur ex principiis speciei, et dicuntur propria sicut risibile homini; quaedam vero causantur ex principiis individui. Et hoc dicitur quia, vel habent causam permanentem in subiecto, et haec sunt accidentia inseparabilia, sicut masculinum et femininum et alia huiusmodi; quaedam vero habent causam non permanentem in subiecto, et haec sunt accidentia separabilia, ut sedere et ambulare. Est autem commune omni accidenti quod non sit de essentia rei, et ita non cadit in definitione rei" (TOMÁS DE AQUINO. Questōes Disputadas Sobre a Alma, 2013, q. XII, ad. 7).

${ }^{12}$ ARISTÓTELES, 2010, III, cap. 4.

${ }^{13} \mathrm{Ou}$, nas palavras de uma historiadora: “Declaro-me, portanto, uma firme crente na 'falácia absurda' de que os fatos históricos existem independentemente do historiador" (TUCHMANN, 1991, p. 19).

${ }^{14}$ TOMÁS DE AQUINO, Suma de Teología, 1953, I, q. 84, a. 7.

${ }^{15}$ Ibidem, I, q. 10, a. 5).
} 
a inteligibilidade dos entes no plano natural, mas não no sobrenatural; e a inteligência divina opera na eternidade e esgota não apenas a inteligibilidade dos entes como é também a própria causa dessa inteligibilidade.

Tenhamos em vista estas distinçôes, ao frisar que o pensamento de Deus não é como o dos anjos e muito menos como o dos homens. ${ }^{16}$ Quando quer, Deus, ao pensar, cria a realidade pensada, arrojando os entes do nada (ex nibilo). É justamente por meio deste pensamento criador que a inteligência divina produz as coisas no ser, segundo toda a sua substância (producere rem in esse secundum totam suam substantiam). ${ }^{17}$ Neste contexto, cumpre lembrar que nem toda ciência divina é prática, uma vez que Deus pode pensar o que "nem fez, faz ou fará”, tal como pode pensar o mal, do qual, para Tomás, certamente não é o autor. ${ }^{18}$ Seja como for, neste ato criador divino, não há trânsito da potência ao ato, pois, sendo Deus Ato Puro sem mescla de nenhuma potência passiva, o que Ele quer criar faz-se instantaneamente, sem movimento. ${ }^{19}$

Em contrapartida, entre o que nós pensamos e o que entendemos há um trânsito. Muitas vezes, é preciso o esforço de uma vida inteira para entender determinadas matérias. Nossa inteligência pressupóe um anterior e um posterior: antes, não conhecíamos Matemática, agora conhecemos; antes, conhecíamos um fato histórico interpretado à luz de certos princípios, hoje náo conhecemos da mesma forma, porque o interpretamos à luz de outros princípios. Por sua vez, a inteligência divina é a de um Ser que está para muito além da realidade dos entes. Ele é imóvel metafisicamente e, pelo fato

16 "Os meus pensamentos não são os vossos pensamentos, e os vossos caminhos não são os meus caminhos, oráculo de Iahweh” (Is 55, 8).

${ }^{17}$ TOMÁS DE AQUINO, Questōes Disputadas Sobre a Alma, 2013, d. 1, art. 2.

${ }^{18}$ TOMÁS DE AQUINO. Suma de Teología, 1953, I, q. 15, a. 3.

19 "Ad secundum dicendum quod creatio non est mutatio nisi secundum modum intelligendi tantum. Nam de ratione mutationis est, quod aliquid idem se habeat aliter nunc et prius, nam quandoque est idem ens actu, aliter se habens nunc et prius, sicut in motibus secundum quantitatem et qualitatem et ubi; quandoque vero est idem ens in potentia tantum, sicut in mutatione secundum substantiam, cuius subiectum est materia. Sed in creatione, per quam producitur tota substantia rerum, non potest accipi aliquid idem aliter se habens nunc et prius, nisi secundum intellectum tantum; sicut si intelligatur aliqua res prius non fuisse totaliter, et postea esse. Sed cum actio et passio conveniant in substantia motus, et differant solum secundum habitudines diversas, ut dicitur in III Physic., oportet quod, subtracto motu, non remaneant nisi diversae habitudines in creante et creato. Sed quia modus significandi sequitur modum intelligendi, ut dictum est, creatio significatur per modum mutationis, et propter hoc dicitur quod creare est ex nihilo aliquid facere. Quamvis facere et fieri magis in hoc conveniant quam mutare et mutari, quia facere et fieri important habitudinem causae ad effectum et effectus ad causam, sed mutationem ex consequenti" (TOMÁS DE AQUINO. Suma de Teología, 1953, I, q. 45, art. 2, ad. 2). 
de o tempo ser a medida do movimento, Deus não se move, Ele está fora do tempo e possui, como Próprio Ser Subsistente, uma inteligência criadora. Por isso, Tomás de Aquino afirma que Deus pode criar por meio de Seus pensamentos. ${ }^{20}$ Por sua vez, o anjo, quando pensa, intui a realidade, e o homem, a abstrai das coisas.

São, portanto, três degraus:

1) a inteligência de Deus, que é criadora,

2) a inteligência do anjo, que é intuitiva e

3) a inteligência do homem, que é abstrativa.

Os animais não abstraem nada. Estão arrojados do mundo da sensibilidade. São, por isso, incapazes de ciência: vivem no ser, porém, agem por instinto e não têm potência para a verdade, a qual reina na esfera imaterial do inteligível.

\section{Deus}

Ele está fora do tempo e todas as coisas provieram da Sua mente, visto serem produto das ideias divinas. Em suma, tudo o que é proveio da mente de Deus. Neste contexto, dizemos que Deus tem presciência dos futuros contingentes - ou seja, de maneira análoga à de um matemático, à de um geômetra ou à de um aritmético, que sabe, por exemplo, que “[...] todo corpo imerso, total ou parcialmente, em um fluido em equilíbrio, sofre a ação de uma força vertical, para cima, aplicada pelo fluido" (Princípio de Arquimedes) ${ }^{21}$ Deus tem em Si mesmo - como causa suprema, universal e perfeita - o conhecimento de todos os efeitos d'Ele dependentes, metafisicamente.

Como Deus está fora do tempo, o tempo não é a medida do Seu ser (o tempo mede o nosso ser: nascemos, crescemos, nos desenvolvemos, envelhecemos e morremos). O tempo é a contagem da mudança de estados e de formas nos entes compostos de matéria e forma. No caso humano: conta desde o nascimento até perdermos a forma humana, virarmos cadáver e sermos consumidos por organismos microcelulares. Assim, o tempo mede os

\footnotetext{
${ }^{20}$ Por sua vez, Aristóteles assevera, em sua Metafisica, que, quando Deus pensa, movimenta o universo (ARISTÓTELES, 2005, Livro XII).

${ }^{21}$ Ou entấo o Teorema de Pitágoras: "Em qualquer triângulo retângulo, o quadrado do comprimento da hipotenusa é igual à soma dos quadrados dos comprimentos dos catetos”. Ver STRATHERN, 1999.
} 
entes e, portanto, a nossa ciência é filha do tempo, não obstante nos dê certa presciência de coisas futuras, sempre com predeterminados limites. Se, neste ponto, usarmos a analogia de proporcionalidade própria, tâo cara ao Aquinate, chegaremos à conclusão de que Deus, por ser a própria eternidade, ${ }^{22}$ tem absoluta presciência de tudo o que se dá.

Devido ao fato de ser qualitativamente infinita, já que não tem mescla de matéria e forma, nem de substância e acidentes, nem de essência e ser, ou seja, por ser Ato Puro, a inteligência de Deus é proporcional à infinitude de Seu ser. Assim, todas as coisas que Ele conhece fora de Si mesmo estáo arrojadas no tempo ou no evo (caso das substâncias imateriais, de que não tratamos aqui), e são, portanto, provenientes da Sua mente criadora. Ele as conhece em seus princípios universais, ou seja, n’Ele próprio.

Conhecendo-Se perfeitamente, Deus conhece o que é, o que foi, o que era, o que será e o que seria. Ou seja, Deus conhece os futuros contingentes - o que virá ou poderia vir a ser. Ele sabia, por exemplo, que Adão pecaria, que Cristo se encarnaria, que o homem precisaria ser redimido. É neste contexto teológico-metafísico que Santo Agostinho diz felix culpa ("Feliz culpa que mereceu tal Redentor"): ${ }^{23}$ Deus sabia que Adão pecaria e desde a eternidade tinha provisto o remédio.

Daí "providência", do latim providere: ver com antecedência e prover os meios adequados os fins a que se ordenam.

\section{A PRESCIÊNCIA DE DEUS}

A lei da divina providência é a presciência de Deus aplicada a todas as criaturas, em todas as suas formas. Deus sabe tudo o que acontecerá, como o número dos eleitos, por exemplo. É a predestinação. Ele sabe quantos e quem serão os eleitos. O problema teológico que não se pode resolver nesta vida é saber quais foram os motivos pelos quais Deus teve dileção especial por alguns, ao ponto de lhes dar aquilo que se chama graça da perseverança final na hora

22 "Respondeo dicendum quod aeternitas vere et proprie in solo Deo est. Quia aeternitas immutabilitatem consequitur, ut ex dictis patet. Solus autem Deus est omnino immutabilis, ut est superius ostensum" (TOMÁS DE AQUINO, Suma de Teología, 1953, I, q. 1, q. 10, art. 3, resp.).

${ }^{23}$ Passagem de uma importante obra de Santo Agostinho, Enchiridion de fide, spe et caritate (Manual sobre a fé, a esperança e a caridade, escrito por volta de 421), posteriormente citada por Santo Tomás (1953, 3, p. 1, a 3). Para essa obra de Santo Agostinho, ver DETONI, Emerson, in: COSTA, 2010, p. 99-116. 
da morte, como deu ao Bom Ladrão. ${ }^{24} \mathrm{Ou}$ seja, a alguns, Ele tira a graça e se perdem. Seja como for, a presciência de Deus a respeito dos predestinados (tanto dos eleitos como dos réprobos) não lhes tira a liberdade de ação.

No âmbito dos fatores até aqui arrolados, vale frisar: é impossível não se cumprir algo que Deus quer. ${ }^{25} \mathrm{~A}$ inteligência d'Ele é instantânea e criadora. Se Deus náo quisesse positivamente que houvesse mal no mundo, não haveria mal algum. Por isso, afirma Santo Tomás: "Deus, na sua presciência, nem quer o mal nem quer não querê-lo" ${ }^{26}$ Ele permite o mal em vista de bens infinitamente superiores, previstos e provistos por Sua presciência, desde a eternidade. Assim foi com a Encarnação: Deus permitiu que o homem pecasse, mas a Sua presciência acerca desse pecado ordenou um meio de reparação supereminente: encarnou-Se e, pela uniáo hipostática, mostrou ao homem a face divina, com o propósito de conduzir os homens à glória para a qual foram criados.

A presciência de Deus dos futuros contingentes, em primeiro lugar, significa isto: a Sua inteligência criadora está fora do tempo. Ela é a causa de todas as criaturas, desde a matéria prima até os anjos, o homem e todas as demais formas. Ou seja, é uma inteligência essencialmente eficaz e perfeitíssima. A nossa é acidentalmente eficaz e sempre imperfeita.

Como afirmava Aristóteles, nunca conseguiremos, nesta vida, ter a posse de todos os inteligíveis da ordem do ser. ${ }^{27}$ Só uma inteligência infinita poderia conhecer o ser das coisas infinitamente.

\footnotetext{
24 "Um dos malfeitores que estavam pendurados blasfemava dele, dizendo: Se tu és o Cristo, salva-te a ti mesmo, e a nós. Respondendo, porém, o outro, repreendia-o, dizendo: Tu nem ainda temes a Deus, estando na mesma condenação? E nós, na verdade, com justiça, porque recebemos o que os nossos feitos mereciam; mas este nenhum mal fez. E disse a Jesus: Senhor, lembra-te de mim, quando entrares no teu reino. E disse-lhe Jesus: Em verdade te digo que hoje estarás comigo no Paraíso" (Lc, 23, 39-43).

25 "Disse Deus: faça-se a luz. E a luz foi feita" (Gn 1, 3).

26 "Como Deus pode conhecer previamente as açôes livres dos homens? Deus decretou todas as coisas, e as decretou com suas causas e condiçóes na exata ordem em que ocorrem, portanto sua presciência de coisas contingentes (ISm 23:12; IIRs 13:19; Jr 38:17-20; Ez 3:6 e Mt 11:21) apoia-se em seu decreto. Deus não originou o mal mas o conheceu nas açōes livres do homem (conhecimento necessário), o decretou e preconheceu os homens. Portanto a ordem é: conhecimento necessário, decreto, presciência. A presciência de Deus é muito mais do que saber o que vai acontecer no futuro, e seu uso no N. T. é empregado como na LXX que inclui Sua escolha efetiva (Nm 16:5; Jz 9:6; Am 3:2). Veja Rm 8:29; IPe 1:2; Gl 4:9” (FERRAZ, 2014).
}

${ }^{27}$ ARISTÓTELES, 2005, Livro VII, 1037a. 


\section{A presciência no LIVRo da ContemplaÇáo, de Ramon Llull}

Mui santo e glorioso é o Vosso saber, Senhor! Louvado e abençoado seja ele! Pois tudo o que os homens pensam e cogitam em seus coraçôes e em seus pensamentos, o bem ou o mal, tudo sabeis Vós. ${ }^{28}$

Feitas estas breves consideraçóes tomistas acerca da ciência, da verdade e da presciência divina, prosseguimos com a meditação do filósofo Ramon sobre o tema, em sua primeira obra de fôlego (e que antecipou, em gérmen, sua filosofia): o Livro da Contemplação (c. 1271-1273). Ao invés do rigor lógico da mente treinada de Tomás de Aquino, o tom aqui é intimista, confessional, devocional:

Ah, Senhor Deus! Se Vosso abençoado saber é para Vós motivo de glória e de honra, não o é o meu, pois confesso meu desconhecimento, minha desobediência, culpa, ignorância, além de todos os vícios. Portanto, como sei que sou assim, vil, mesquinho e doente, meu saber é para mim ocasião de lágrimas, de dores, de arrependimentos, e oportunidade de conhecer minha frivolidade e mesquinhez. ${ }^{29}$

Llull divide sua apreciação contemplativa sobre a ciência divina em três capítulos: "Como Deus é ciente em Sua essência divina", "Como sabe todas as coisas que são e quais são" e "Como sabe tudo o que as criaturas fazem". Seu diálogo com Deus é desenvolvido em uma progressão binária, frontal: Deus e a criatura, o Infinito e a finitude, a Eternidade e o perecível. Para o filósofo, é maravilhoso constatar a imensidáo da ciência divina e, em contrapartida, como o saber humano é finito. Quem pode imaginar a grandeza e a nobreza do conhecimento divino? Seu alcance é incalculável, e sua generosidade é infinita, pois nos foi concedida a capacidade de entender as Suas qualidades essenciais: Justiça, Honra, Sabedoria, Poder, Eternidade, Glória. Neste ponto,

28 "Molt és sant e gloriós, Sènyer, lo vostre saber: loat e beneit sia ell. Car en tot ço que los hòmens pensem ni cogiten en lurs cors ni en lurs penses, sia bé o sia mal, tot o sabets vós". "Molt és sant e gloriós, Sènyer, lo vostre saber: loat e beneit sia ell. Car en tot ço que los hòmens pensem ni cogiten en lurs cors ni en lurs penses, sia bé o sia mal, tot o sabets vós". Llibre de contemplació, Volum primer, VII Distinció, capítol XXI, 7 (LLULL, 1957, p. 144).

29 "Ah sényer Déus! Si.l vostre beneit saber és a vós glória e honor, no és enaixí del meu, car jo.m sé desconeixent, e desobedient, e culpable e ple de tots vicis e de tota desconeixença. On, per ço com jo.m sé aital, així vil e mesquí e àvol, és a mi mon saber ocasió de plors, e de dolors, e de penediments, e de conèixer la mia frevoltat e mesquinea". Llibre de contemplació, Volum primer, VII Distinció, capítol XIX, 12 (LLULL, 1957, p. 141). 
o maiorquino apresenta uma analogia agostiniana que iria tornar-se recorrente em sua obra: o saber de Deus é como o óleo sobre a água: ${ }^{30}$

\begin{abstract}
Pois assim, Senhor, como o óleo naturalmente roda sobre a água, Vosso saber é mais elevado que o nosso, e, por isso, náo podemos saber tanto quanto Vós. Ainda, Senhor, poderíamos entender e saber muito mais se não fosse o pecado original, que fez com que o nosso conhecimento fosse cegado e entorpecido pelo pecado de Adáo e, por isso, a nossa alma e o nosso corpo, por estarem unidos, sáo simultaneamente culpados, já que muito mais entenderíamos e saberíamos se não tivesse havido o pecado original. ${ }^{31}$
\end{abstract}

Deus pode ser conhecido pelo homem por intermédio das criaturas criadas. Elas expressam uma parcela infinitesimal de Sua essência. Em contrapartida, o conhecimento humano, débil, melhora quando se aproxima de Deus, para amá-Lo e conhecê-Lo. Nessa contemplação amorosa, a criatura reconhece sua enorme dificuldade de apreender a substância das coisas. Em contrapartida, Deus conhece tudo o que existe, dos anjos à alma. Em relação a esta última, Llull cita uma passagem de 1 Tessalonicenses $(5,23)$, para demonstrar a sua estupefação com as limitaçôes do conhecimento humano.

E se isso não é o bastante, Senhor, não me maravilho, pois em muitas coisas simples ela falha, já que não é suficiente para entender nem conhecer, pois mesmo que eu saiba que existem três coisas em minha humanidade, isto é, o corpo, a alma e o espírito, eu não sei o que minha alma é em si mesma, nem qual coisa é. ${ }^{32}$

${ }^{30}$ Passagem das Confissóes, quando Agostinho narra o descortinar do mistério divino: "Em seguida aconselhado a voltar a mim mesmo, recolhi-me ao coração, conduzido por Vós. Pude fazê-lo, porque Vos tornastes meu auxílio. Entrei, e, com aquela vista da minha alma, vi, acima dos meus olhos interiores e acima do meu espírito, a Luz imutável. Esta não era o brilho vulgar que é visível a todo o homem, nem era do mesmo gênero, embora fosse maior. Era como se brilhasse muito mais clara e abrangesse tudo com a sua grandeza. Não era nada disto, mas outra coisa, outra coisa muito diferente de todas estas. Essa Luz náo permanecia sobre o meu espírito como o azeite em cima da água, ou como o céu sobre a terra, mas muito mais levada, pois Ela própria me criou e eu sou-lhe inferior, porque fui criado por Ela" (AGOSTINHO, 1998, VII, 10, 16 - tradução nossa). Para uma excelente análise do tema, na obra de Ramon Llull, ver BATALLA, Josep; FIDORA, Alexander. Introducció. In: LLULL, 2011a, p. 35-41.

31 "Car enaixí, Sènyer, com l'oli per natura roda sobre l'aigua, enaixí lo vostre saber és pus alt que.l nostre, e per açò nós no podem saber tant com vós sabets. Encara, Sènyer, que.l nostre saber s'abcegà e s'engruixà en Adam com pecà, en ço que l'ànima nostra e.l cors nostre n'és enculpada ensems, sempre que són ajustats, car molt més enteserém e sabérem, si.l pecat original no fos". Llibre de contemplació, Volum primer, VII distinció, capítol XIX, 18 (LLULL, 1957, p. 141).

32 "E si no hi basta, Sènyer, no me'n meravell, car en pus leugeres coses defall, que no pot bastar a entendre ni a conèixer, car jassia ço que jo sàpia la mia humanitat ésser tres coses, cors e ànima $\mathrm{e}$ 
Essa divisão tripartida do homem se encontra nas Epistolas de Paulo de Tarso (c. 4-57). O espírito pode ser interpretado como um dos efeitos espirituais da ação santificadora divina. Paulo serve a Deus em seu espírito (pneuma, $\pi v \varepsilon v ́ \mu \alpha$ ), parte superior do homem, e assim anuncia o evangelho de seu Filho. ${ }^{33}$ Há, portanto, certa correspondência análoga entre o espírito do homem e o Espírito de Deus. Por isso, em Llull, que nesse aspecto segue Paulo quase pari passu, a incompletude do conhecimento humano em relação à sua própria humanidade deve fazer com que se aproxime amorosamente de Deus para, assim, também, conhecer a si mesma.

Além da alma, o tempo é outro mistério para Ramon Llull: nosso saber, ínfimo em relação ao de Deus, não pode conhecer a hora do princípio que começamos a ser, tampouco o instante em que deixarmos de estar no mundo. E o agora?

Toda esta fraqueza recai, Senhor, em nosso saber, por razão da pequenez e sutileza que existe no agora e em qual tempo está, pois este agora existe em uma quantidade tão ínfima e táo rápida do tempo passado ao vindouro que nosso entendimento não consegue perceber sua pequena quantidade, nem a ligeireza que possa atingir sua velocidade e rapidez. ${ }^{34}$

Percebe-se que as meditaçôes lulianas sobre a ciência divina são uma oportunidade para o filósofo manifestar sua estupefação com a mediocridade do saber humano. Ademais, ao tratar de como Deus conhece instantaneamente tudo o que fazemos e faremos, Ramon discorre sobre o conhecimento divino a respeito das criaturas: anjos, demônios, o firmamento e os corpos celestiais, os quatro elementos, os metais, os animais, os vegetais e "qualquer outra coisa feita”: Deus sabe o que pensamos e o que fazemos, e com qual intenção, no tempo pretérito e no vindouro, quando então lamenta e diz sentir vergonha e temor por não saber o que será.

espirit, per tot jo no.m sé la mia ànima què és en si mateixa ne quina cosa és". Llibre de contemplació, Volum primer, VII distinció, capítol XIX, 21 (LLULL, 1957, p. 141).

33 "Deus, a quem sirvo em meu espírito, anunciando o evangelho do seu Filho, é testemunha de como me lembro continuamente de vós em minhas oraçóes, pedindo que, de algum modo, com o beneplácito de Deus, se me apresente uma oportunidade de ir ter convosco" (Rm 1, 9).

34 "Tot aquest defalliment cau, Sènyer, en lo nostre saber, per raó de la poquea e subtilea que és en l'ara en qué temps està; car aquell ara és tant de poca quantitat e és tan ivaçosa del temps passat a l'esdevenidor, que lo nostre enteniment ni pot apercebre sa poca quantitat, ni li leu que pusca atènyer son corriment e sa ivarsea". Llibre de contemplació, Volum primer, VII distinció, capítol XX, 12 (LLULL, 1957, p. 143). 


\begin{abstract}
Ah, Senhor Pai! Maioria, medida e misericórdia sejam conhecidas em Vós e em Vosso saber, pois este sabe todas as falsidades, maldades, feiúras eu que cometi, disse, cogitei, pensei. Por isso, eu, Senhor, estou muito envergonhado diante do Vosso abençoado altar.

Pois, quando eu penso e recordo as faltas que cometi em minha juventude, e sei que Vós sabeis tudo, não é nenhuma maravilha que eu tenha vergonha e pavor de Vós, maiormente por náo saber o que Vós fareis comigo, isto é, se me perdoará ou me condenará. ${ }^{35}$
\end{abstract}

\title{
V. Conclusáo
}

Como se pode ver com clareza, trata-se de duas perspectivas bastante distintas: a metafísica de Santo Tomás e a alegórica de Llull. Ambas, no entanto, apontam para uma mesma realidade: a) A ciência de Deus é perfeitíssima e omniabarcante, e a do homem, imperfeita e limitada, b) Deus tem a presciência de tudo o que criou, e c) as criaturas dotadas de inteligência, por sua vez, logram uma ciência que não pode esgotar a inteligibilidade dos entes. E não a pode esgotar simplesmente porque os entes participam metafisicamente da inesgotabilidade da essência divina. Assim, por mais que conheçamos as coisas, sempre haverá algo mais por conhecer, e mesmo na contemplação da essência divina — por parte dos bem-aventurados — o mistério perdurará.

O mistério do ser. Este só pode ser elucidado por Aquele que é o Próprio Ser, Deus mesmo.

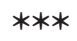

\footnotetext{
35 "Ah, Pare, Senyor! Majoria e mesura e misericòrdia sia coneguda a vós e al vostre saber, car aquell sap totes quantas falsies ni avolees ni legees jo anc fiu, ni dix, ni cogité, ni pensé; per què jo Sènyer, dec estar molt vergonyós denant lo vostre beneit altar. Car, com jo.m pens e remembre en los defalliments que he fets em ma joventut, e sé que vós los sabets tots, si he vergonya ni paor de vós, no és nulla meravella; e majorment com jo no sàpia vós què farets de mi, si.m perdonarets o si.m damnarets". Llibre de contemplació, Volum primer, VII distinció, capítol XXI, 28-29 (LLULL, 1957, p. 146).
} 


\section{O LIVRO DA CONTEMPLAÇÃO}

RaMON Llull (1232-1316)

\section{Distinçáo - Da CIÊNCIA DIVINA}

\section{Cap. XIX - Como Deus é ciente em Sua essência divina ${ }^{36}$}

1. Deus elevado, soberano, excelente, completo, abençoado, honrado, amado, temido e servido! É tão grande e nobre a Vossa ciência que não poderia ser maior, pois como Vós sois uma essência infinita, sabeis e conheceis inteiramente a Vós mesmo. Por isso, convém que Vossa ciência seja infinita.

2. Ah, Senhor Deus! Se a nós parece coisa maravilhosa a imensidão de Vossa ciência, não me maravilho que nosso saber seja finito, mas quão maravilhoso é o saber infinito.

3. Ah, Senhor dos senhores! Náo é nada saber o que pode ocorrer conosco, pois todo saber é finito, a náo ser o Vosso. Portanto, Senhor, como poderia o saber finito se elevar até o Vosso, que é infinito? Isso é, Senhor, impossível.

4. Honrado Senhor, Deus glorioso. Abençoado sejais Vós e o Vosso saber, que é tão grande e eterno, pois assim nunca a eternidade e o Vosso saber se separarão, pelo contrário, estarão juntos do início ao fim.

5. Amável Senhor, não há nenhum saber que ouse se aproximar ou se comparar ao Vosso, pois todo saber, até onde sei, tem princípio e fim. Mas o Vosso saber não tem princípio nem fim, pelo contrário, sabe infinitamente.

6. Elevado e bem-aventurado Senhor, o que pode saber tanto que ultrapasse ou seja suficiente para alcançar o que Vosso saber abrange? E quem é que pode considerar a Vossa grandeza e nobreza? Não é possível, Senhor, conhecer toda a Vossa bondade e, por isso, o nosso saber não pode se elevar até onde o Vosso saber alcança.

7. Oh, Vós, Senhor Deus, que sois Rei dos reis e venceis e forçais a quem desejais! Se o rei fica alegre e feliz quando sabe que tem poder sobre seu povo para fazer o que deseja, náo me digais, Senhor, quantas ocasióes o Vosso saber vos proporciona alegria!

${ }^{36}$ Tradução: Ricardo da Costa. Base da tradução: LLULL, 1960, p. 140-146. 
8. Como Vós sabeis que Vós sois Deus, incorruptível, sem princípio nem fim, que não pode ser constrangido, e sabeis que Vós sois um Criador, um Senhor, portanto, Senhor, quem poderia calcular o grande bem que sois quando sabeis que sois assim?

9. Ah, Senhor Deus! Como o Vosso santo saber é tấo honrado e de táo elevada virtude, qual coração poderia atingir Vossa bondade, quais olhos poderiam ver e quais ouvidos poderiam ouvir os louvores que vos correspondem?

10. Senhor servido e amado, acima do qual nada tem ação ou poder, e que tem ação e senhoria acima de todas as coisas! Vós sabeis muito bem que o homem justo, que sabe que está em bom estado e é inocente, sem qualquer culpa, é muito alegre, pois sabe que é justo.

11. Portanto, se tal saber, Senhor, alegra os homens justos, quanto mais Vós deveis ser glorioso, pois sabeis que sois justo, inocente, reto, que nunca pensou, nem fez, nem disse nada contrário à Vossa bondade ou sabedoria!

12. Ah, Senhor Deus! Se Vosso abençoado saber é para Vós motivo de glória e de honra, não o é o meu, pois confesso meu desconhecimento, minha desobediência, culpa, ignorância, além de todos os vícios. Portanto, como sei que sou assim, vil, mesquinho e doente, meu saber é para mim ocasião de lágrimas, de dores, de arrependimentos, e oportunidade de conhecer minha frivolidade e mesquinhez.

13. Verdadeiro Senhor, amante da verdade e do conhecimento! Como Vós sabeis que Vossa glória é grande e nobre, imensa glória é saber que sois tão glorioso, pois, de acordo com a grandeza da glória, é grande o saber. Assim, como a glória vos glorifica, o mesmo faz o saber.

14. Ainda, Senhor, grande é o Vosso saber em nobreza e em glória, pois como sabeis que a glória que existe em Vós é de Vós e não de outro, é elevado o Vosso saber em virtude e em santidade, quando sabe toda a glória que existe em Vós.

15. Ah, Senhor! Como sabeis que sois toda a nossa glória e nenhuma outra coisa nos glorifica no Paraíso a náo ser Vós, Senhor, é muito glorioso e nobre esse saber, pois o vemos muito perfeito e honrado, e a glória não pode vir nem estar em nenhuma outra coisa a não ser de Vós e em Vós.

16. Justo Senhor, pleno de generosidade e de ensinamento, do qual são derivadas e oriundas todas as nossas forças! Bendito sejais Vós, Senhor, 
pois ainda que o nosso saber seja táo pequeno e tênue, a ponto de não conseguirmos atingir o conhecimento do que é Vossa essência, pelo menos vos agradou termos demonstrado o ser no ser de Vós, e haveis desejado que não chegássemos a Vós por outro caminho a não ser pelo Vosso.

17. A razão, Senhor, pela qual nós não conhecemos o que é a Vossa essência deve-se à Vossa grande excelência e nobreza, além da mesquinhez e fraqueza do nosso saber.

18. Pois assim, Senhor, como o óleo naturalmente roda sobre a água, Vosso saber é mais elevado que o nosso, e, por isso, não podemos saber tanto quanto Vós. Ainda, Senhor, poderíamos entender e saber muito mais se não fosse o pecado original, que fez com que o nosso conhecimento fosse cegado e entorpecido pelo pecado de Adão e, por isso, a nossa alma e o nosso corpo, por estarem unidos, são simultaneamente culpados.

19. Louvores, reverências e honras sejam concedidas, Senhor, ao Vosso bem-aventurado saber, que faz e nos dá a capacidade de entender em Vós qualidades essenciais, pois, através dessas qualidades, conseguimos certificar ao nosso entendimento e conhecimento de que Vós sois unido em Trindade e que Vossa Trindade é una.

20. Contudo, Senhor, até que saibamos que a Vossa substância divina são três pessoas, não temos entendimento nem conhecimento do que é Vossa substância em Si mesma, pois é tão profunda coisa de saber que nosso entendimento não é suficiente para tal.

21. E se isso não é o bastante, Senhor, não me maravilho, pois em muitas coisas simples ela falha, já que não é suficiente para entender nem conhecer, pois mesmo que eu saiba que existem três coisas em minha humanidade, isto é, o corpo, a alma e o espírito, eu não sei o que minha alma é em si mesma, nem qual coisa é. ${ }^{37}$

22. Santo Senhor, ajuda e esperança nossa! O Vosso saber, reconheçamos, é inteiramente nobre, inteiramente completo e inteiramente bom, e sabe que não é nada ser conveniente faltar em nós o conhecimento do Vosso saber.

23. O Vosso glorioso saber, Senhor, muito se distancia do nosso, pois sabemos o que sabemos graças a um meio que proporciona a ocasião de sabermos.

37 "E o mesmo Deus de paz vos santifique em tudo; e todo o vosso espírito, e alma, e corpo, sejam plenamente conservados irrepreensíveis para a vinda de nosso Senhor Jesus Cristo" (1 Tessalonicenses 5:23). 
Mas Vós, Senhor, o que sabeis, sabeis sem qualquer meio. Por isso, Vosso saber manifesta e mostra ser grande, e o nosso ser pequeno.

24. Ah, Senhor Deus! Como nós sabemos que Vós sois inteiramente bom e completo, e temos esse conhecimento através da significação das criaturas que o demonstram, quanto mais Vós, que sabeis que sois bom e completo, pois nada que é o demonstra, a não ser por Vós mesmo.

25. Bem forte e grande, Senhor Deus, é este Vosso saber, e o que é muito forte é nobre, porque o nosso saber cresce e melhora, quando se aproxima de Vós para amá-Lo e conhecê-Lo, e ele é bom e grande por Vossa razão. Portanto, Senhor, deve ser bem grande e nobre o Vosso saber, que é ciente de Sua própria bondade, quando conhece toda a bondade de Vossa essência.

26. Ah, Senhor! Como o nosso saber cresce e se multiplica em Vós, direi, Senhor, a todos os meus íntimos, vizinhos e amigos que me ajudem a contemplá-Lo conforme as palavras deste livro. E isso lhes direi, Senhor, para que seu saber e o meu sejam engrandecidos em Vós.

27. Pois se nós, Senhor, podemos ser tais que contemplemos a Vós com todo o nosso poder e todo o nosso coração, conforme o ordenamento deste livro, de tal modo, Senhor, nosso saber em Vós se engrandecerá e ganhará virtude, de tal modo que não será a fome, a sede, a dor ou a tristeza que nos prejudicará ou desviará de Vosso amor.

28. Soberano Senhor, nobre e honrado! Convém, Senhor, que adoremos, honremos e roguemos o Vosso santo saber, pois ele é externo aos limites nos quais o nosso saber está posto.

29. Nosso saber, Senhor, é algo tão mesquinho e ínfimo que toda mesquinharia e pequenez lhe devem ser atribuídas, pois é pequeno e pouco dura, e poucas são as coisas que sabemos.

30. Ah, Senhor Deus! Como o meu saber é tão débil e tão mesquinho que está preparado para receber toda ignorância e pequenez, rogo-vos, Senhor, que não deixeis que eu esqueça a nobreza, a virtude e a honraria de meu Senhor Deus.

\section{Cap. XX - Como Deus sabe todas as coisas que são e Quais são}

1. Senhor Deus, adoremos, supliquemos, honremos e amemos a Vós, que sois ciente do que é a substância angélica em si mesma, pois Vós a haveis 
criado e ordenado. Por isso, não é uma maravilha, Senhor, Vós terdes conhecimento dela.

2. Amoroso Senhor, bom, benigno e bem-aventurado! Se Vós sabeis o que é a substância angélica em si mesma, nós não o sabemos, porque nós, Senhor, ainda que tenhamos conhecimento de que o anjo é substância espiritual, não sabemos o que é sua substância em si mesma, ou qual coisa é. E esta fraqueza está em nosso saber, porque o ser de Sua substância é oculto aos nossos cinco sentidos corporais.

3. Ah, Senhor santo, conhecedor, doce, generoso! Se a substância angélica está oculta ao nosso saber, porque não é feita uma representação aos nossos cinco sentidos espirituais pelos corporais, não é oculta ou obscurecida ao Vosso saber, pois não é conveniente que ao Vosso saber seja feita outra representação nem outra demonstração, já que tudo sabe.

4. A Vós, Senhor, que sois a glória dos católicos, sejam conhecidas a força, a eternidade, a grandeza e a graça, pois o ser da alma racional é sabido e conhecido por Vós, já que criastes a alma, e a principiastes, a ordenastes e a sustentastes. Portanto, Senhor, abençoado sejais Vós, que tanto sabeis que nada Vos é oculto, nem há nada que saiba tanto quanto Vós.

5. E, Senhor Deus, amado e honrado sejais Vós, pois se Vós sabeis as nossas almas, não o sabemos nós, Senhor, ainda que sejamos indivíduos unidos de alma e corpo. Nós não sabemos isso, Senhor, porque não nos foi feita uma representação aos sentidos corporais nem aos espirituais.

6. Isso é, Senhor, quase uma maravilha - que exista a alma e não saibamos o que é em si mesma. Contudo, Senhor, que bem pensa, não considera isso nenhuma maravilha, por razão da imensa pequenez e enorme debilidade que existe em nossa ciência.

7. Louvor, infinitude, excelência e nobreza sejam conhecidas em Vós, Senhor, que alegra e consola os justos, pois Vós, Senhor, sois aquele que tem o conhecimento da matéria e da forma do firmamento, dos elementos simples e dos compostos, pois o que é sua matéria e forma são conhecidas pelo Vosso santo saber, pois Vós haveis criado tudo e tudo feito, e Vós tendes tudo em ordenação.

8. Ah, Senhor benigno! Nosso saber não é como o Vosso, pois, ainda que tenhamos um corpo composto pelos quatro elementos, por tudo isso, Senhor, como nós entendemos a matéria no entendimento e participamos 
de sua forma, não temos tanto saber nem entendimento para saber ou entender o que é a matéria em si mesma.

9. É uma grande maravilha, Senhor, que não saibamos o que não sabemos nem entendemos o que é em si mesmo. Assim, como nos faltam saber e entendimento para conhecer o que somos, quanto mais, Senhor, nos deve faltar saber para conhecer o que é Vossa substância em Si mesma!

10. A Vós, Senhor, que abençoais a quem Vós desejais, reconheçamos Vossa grandeza, honraria e nobreza, pois conheceis e sabeis o que está no tempo, já que Vós o haveis criado.

11. Ao nosso saber, Senhor Deus, atribuímos vilania e mesquinhez, e isso, Senhor, porque nosso saber não é suficiente para saber a hora que existiu no princípio que começamos a ser, nem podemos saber a hora que existirá no fim em que nós deixarmos de estar no mundo, ou a hora em que estamos no presente. Portanto, Senhor, como o nosso saber falha em conhecer essas coisas, qual saber é mais mesquinho e menor que o nosso? E qual saber é tão grande quanto o Vosso?

12. Toda essa fraqueza recai, Senhor, em nosso saber, por razão da pequenez e sutileza que existe no agora e em qual tempo está, pois este agora existe em uma quantidade tão ínfima e táo rápida do tempo passado ao vindouro que nosso entendimento não consegue perceber sua pequena quantidade, nem a ligeireza que possa atingir sua velocidade e rapidez.

13. Piedade, justiça, verdade e misericórdia sejam atribuídas a Vós, Senhor grande e maravilhoso, pois sabeis quando estamos saudáveis e quando ficaremos doentes, já que Vós, Senhor, dais saúde e doença, e fazeis conosco tudo o que desejais.

14. Isso não acontece assim, Senhor, com o nosso saber, pois, mesmo que nos sintamos sãos ou doentes, não sabemos a ocasião pela qual estamos sãos ou doentes antes de estarmos, Senhor, apenas por adivinhação. Prova disso é que muitas vezes pensamos ajudar a nossa saúde e, ao invés disso, nós a pioramos.

15. Logo, grande maravilha é, Senhor, como nosso saber é pequeno e tão pouco virtuoso que o mal está em nós e, para onde quer que vamos, não sabemos expulsá-lo nem fugir dele, pelo contrário, ele estará no meio de nós, sentir-nos-emos morrer, e náo teremos conhecimento daquilo que nos levará à morte. 
16. A Vós, Senhor, que recompensais aqueles que Vos servem, atribuamos e comparemos toda a sabedoria, cortesia e senhoria; façamos isso por razão de Vossa honrada ciência, e atribuamos ao nosso saber toda a rusticidade e toda a servidão, pois ainda que, Senhor, o homem seja a mais nobre criatura, continua sua falha de saber o ser das coisas, ser que é conhecido pela Vossa abençoada sabedoria.

17. Ah, Senhor doce e suave! Quão grande é a falta que existe em nosso saber! Pela falta de saber, nós nos gabamos e nos glorificamos, pois pensamos saber o que não sabemos, afirmamos que sabemos o ser das coisas sem sabê-lo, e não lembramos como nos falta saber o nosso próprio ser.

18. Glorioso Rei da glória! Se os homens orgulhosos e vangloriosos soubessem a pequenez e a frivolidade que existem em seu saber, não seriam tấo altivos nem tão desconhecedores como são, pelo contrário, se humilhariam perante seu Criador, seu Senhor e seu próximo.

19. Que a durabilidade, Trindade, singularidade e unidade sejam conhecidas em Vós, Senhor Deus, que sabeis que, ainda que confessemos e concordemos, que o nosso saber é pequeno e tênue. Por isso, não estamos desculpados de nossas obras, pois muitas vezes somos conscientes de nossa fraqueza, e o somos por falta de conhecimento.

20. Isso porque, Senhor, mesmo que eu não saiba o que é a Vossa ciência, nem meu ser, nem o das criaturas, basta-me tentar saber o que é o ser de Vosso ser, e basta-me sujeitar-me a amar, a honrar e a servir a Vós com toda a minha vontade e todas as minhas forças.

21. Assim, louvado, abençoado, amado e servido sejais Vós, Senhor, pois agradou a Vós terdes posto virtude em nosso entendimento, já que sabemos que somos obrigados a honrar, a temer e a obedecer todos os Vossos mandamentos e todas as Vossas vontades.

22. A Vós, Senhor, que recompensais todos os Vossos bem-aventurados servos, seja conhecida a Vossa primazia e supremacia, glória e virtude, e a mim, Senhor, princípio e fim, fraqueza e mesquinhez, pois tenho, Senhor, tâo pouco saber e entendimento que, pela imundície que em mim havia, muitas vezes me gabava de saber o que não sabia, e repreendia os homens, quando não sabiam o que lhes era impossível de saber.

23. Ah, Senhor Deus, Deus meu e meu Senhor! Bendito sejais Vós, pois até hoje eu não havia percebido a fraqueza que existe em meu saber, mas 
agora, Senhor, percebi e conheci, por Vossa graça. Assim, rogo-Vos que guardeis e salveis esse saber que me destes, apesar de conhecer a pequenez e a mesquinhez de meu saber.

24. Ah, Senhor! Como tanto desejei me gabar e glorificar-me de grandeza e de saber, rogo-Vos, Senhor, que representeis à minha alma a mesquinhez e pobreza que existem em meu saber, e se daquela frivolidade eu desejar me gabar, ter vanglória ou me orgulhar, que eu o faça, mas não me aprecie do que não existe nela.

25. Ah, bem-aventurado Senhor! Ajuda, amor e alteza sejam conhecidas em Vós, que despertais os errantes e os pecadores, pois Vós sois, Senhor, aquele que sabeis arrumar e reparar o que nós apodrecemos e estragamos por falta de saber, pois as coisas que ignoramos não temos conhecimento nem poder de deixar de estragá-las, tampouco sabemos arrumar as que estragamos, táo tênue e mesquinho é o nosso saber.

26. Em contrapartida, o Vosso saber, Senhor, que tudo sabe, é poderoso de proteger e salvar tudo que é bom, e se algo se estraga, podeis corrigir e sabeis melhorar. Assim, se nós, Senhor, não sabemos como melhorarmos, melhore-nos vós, que tendes o poder e o saber.

27. Portanto, Senhor, agrada-nos que o Vosso saber nos abençoe e nos dê a graça. Para isso, basta que nós oremos, $\mathrm{O}$ amemos e $\mathrm{O}$ sirvamos, e assim saibamos contemplar-Vos em vossa sabedoria e em Vossa virtude.

28. Suave Senhor, que endireitais os justos e limpais os pecadores, amizade, bem-aventurança e bondade sejam conhecidas em Vós e em Vosso saber, pois sois tão bom por Vosso saber e por muitas outras virtudes que, em muitas ocasióes podemos e devemos Vos amar e nos tornarmos bons em Vós. E a maior ocasião que temos para sermos bons, Senhor, é quando percebemos em Vosso saber o conhecimento de Vossa imensa bondade.

29. Grande vergonha deve haver em nós, Senhor, pois sabemos que o Vosso abençoado saber é conhecedor de nossa fraqueza, de nosso desconhecimento e de tudo o que erramos e falhamos convosco. Pois, quanto mais Vós valeis, e nós sabemos que Vós sabeis todas as nossas faltas, mais vergonhosas elas devem ser.

30. Ah, Senhor! Como nós sabemos que em Vosso saber somos entendidos como vis e culpados, agrada-nos, Senhor, que conheçamos e saibamos que Vós sois doce, suave e misericordioso, para que nossa esperança não 
se distancie de Vossa grande piedade, nem esfrie nosso amor por Vós, pois sois Nosso Senhor Deus.

\section{CaP. XXI - Como Deus Sabe tudo o QUe as Criaturas fazem}

1. Divino Senhor, a bênção, a santidade e o conhecimento existem em Vós, pois sabeis tudo o que fazem os anjos, tudo o que glorificam, o quanto nos ajudam e todos os lugares a que vão, e sabeis isso, porque os criastes e os ordenastes em tudo o que fazem.

2. De modo semelhante, Senhor, sabeis tudo o que os demônios fazem, pois sabeis todas as suas falsidades, todos os enganos que cometem e todas as maldades que fazem. E sabeis isso, porque eles estão sob o Vosso poder e sob a Vossa sentença.

3. Tudo o que o firmamento e os corpos celestiais fazem, tudo sabeis Vós, Senhor, já que estão em movimento. E as coisas que os corpos celestiais fazem nos corpos elementais também são sabidas por Vós, pois sois aquele que apropriastes as coisas feitas pelo firmamento e seus corpos.

4. Senhor Jesus Cristo, toda concórdia, toda justiça e toda defesa existem de Vós e por Vós, e toda nobreza está em Vós, pois sabeis tudo o que fazem os elementos, em suas mesclas, composiçóes e decomposiçôes.

5. Senhor livre, tão grande é o Vosso saber que Vós sabeis tudo o que fazem os metais, os animais, os vegetais, e qualquer outra coisa feita náo pode se ocultar de Vossa ciência.

6. Antes, Senhor, todo o consolo que alguns animais fazem com outros, ou todo o trabalho que fazem, tudo sabeis Vós. O mesmo com os vegetais, no que são engendrados, corrompidos ou moventes, tudo sabeis Vós, pois os criastes, os ordenastes e os sustentastes no ser.

7. Mui santo e glorioso é o Vosso saber, Senhor! Louvado e abençoado seja ele! Pois tudo o que os homens pensam e cogitam em seus coraçóes e em seus pensamentos, o bem ou o mal, tudo sabeis Vós.

8. Que maravilha, Senhor, que vós saibais tudo o que os homens fazem ou pensam! Pois Vós sois aquele que nos fizestes falar, andar e mover, e vós nos sustentastes e nos colocastes em tudo o que desejais. 
9. Concedamos dignidade, doçura, glória e louvor a Vós e ao Vosso saber, Senhor Deus, e ao nosso saber concedemos e atribuímos frivolidade e pobreza, pois, se o Vosso saber sabe tudo o que fazemos, o mesmo não consegue o nosso saber. Assim, como nós não sabemos nem o que fazemos, bem podemos avaliar a frivolidade e a mesquinhez de nosso saber.

10. Amoroso Senhor, onde toda a generosidade, nobreza e virtude existem! Sois tão pleno e completo de saber, que conheceis todas as nossas vontades. Assim, é grande a nobreza de Vossa ciência, que sabe tantas vontades assim contrárias umas às outras.

11. Não ocorre com o nosso saber o mesmo que com o Vosso, Senhor, pois as vontades que estáo em nós não podem conhecer umas às outras, até que as escutemos ou as percebamos através de semelhanças. E mais: para que saibamos verdadeiramente, náo bastam palavras, signos ou sinais.

12. E há ainda algo mais grave em meu saber, Senhor: não sei quando a vontade que há em mim continuará ou partirá de mim, nem sei a vastidão da contrariedade de meu entendimento.

13. Bem-aventurado Senhor, o Vosso saber sabe tudo o que nós fazemos, e por qual intenção fazemos. Se o fazemos pela primeira intençáo ao nosso olhar, Vós, Senhor, sabeis que pecamos e erramos. Se o fazemos pela primeira intenção ao olhar de Vós para servi-Lo, sabeis que o fazemos por Vossa glória e louvor e para o nosso bem.

14. Ah, verdadeiro Deus! Que a dominação, a excelência e a integridade sejam conhecidas em Vós, que sabeis todas as nossas obras, sejam as virtuosas, sejam as viciadas, e sabeis a maneira e a ocasião pela qual nossas obras mudam, de vícios para virtudes e de virtudes para vícios.

15. Perdurável Senhor, como sois tão sábio e tão perspicaz em tudo o que fazemos, bem-aventurados sejam todos aqueles que vos amam, honram, servem e louvam com a verdadeira intenção. E ai daqueles que, por amor próprio, se esforçam em ser honrados e se deleitarem nesta frívola vida mundana!

16. Quem é, Senhor, que pode imaginar e compreender a grandeza de Vosso saber, que, em um instante, sabe todos os pensamentos dos homens, por mais contraditórios que sejam?

17. Que a eternidade, a divindade e a durabilidade sejam conhecidas no Vosso saber, Senhor, e ao nosso saber princípio e fim, pois não podemos em um 
instante entender diversas coisas, nem diversos pensamentos, pois antes convém que entendamos uma coisa e depois que entendamos outra. Mas Vós, Senhor, sabeis tudo ao mesmo tempo, por mais contraditório que seja e, por mais numerosos que sejam, elas não impedem o Vosso saber.

18. E mais, Senhor: podemos perceber que o nosso saber é pequeno e frívolo, e o Vosso grande e nobre, pois, se dois homens falam coisas contrárias, aqueles que os escutam não conseguem perceber o entendimento das palavras em um instante, pois perdem algumas delas para entender outras. Mas o Vosso saber, Senhor, não é impedido pela multidão de palavras diferentes, pelo contrário, tudo sabe e tudo entende.

19. Dignidade, glória e liberdade atribuímos a Vós, Senhor, e vos comparamos, por razão do Vosso saber, que sabe o tempo passado, o vindouro e o presente. E atribuímos a nós mesquinhez e servidão, porque o nosso saber ignora mais as coisas passadas e vindouras que as presentes.

20. Ah, abençoado Senhor! A ignorância que nós temos das coisas acontece por razão do tempo pretérito e do vindouro, que nos oculta e nos obscurece, devido à sua ausência. E aquele pouco saber que temos deles acontece no tempo presente, pela demonstração e representação que eles fazem aos nossos sentidos corporais.

21. Como as coisas são ausentes em nós em um tempo e não em outro, sentimos maior vergonha dos pecados que cometemos no tempo em que cometemos, que daqueles que fizemos e faremos, mesmo que os que fizemos ou os que faremos sejam pecados tão graves ou piores que aqueles que cometemos. Assim, por falta do nosso saber vindouro, nós deveríamos sentir vergonha daqueles pecados que fizemos ou faremos, assim como sentimos dos que cometemos no presente.

22. A graça, o amor e a honra que Vós, Senhor Deus, haveis feito a nós nos tempos passados, e nós deveríamos louvar, bendizer e dar graças àquela que nos fareis nos tempos vindouros, do mesmo modo que esta que Vós nos fazeis no tempo no qual estamos. Por isso, como nós não o fazemos, ocorre em nós, por desconhecimento, desconhecer as coisas passadas e as vindouras. Portanto, infinitude, grandeza e senhoria sejam atribuídas ao Vosso santo saber, Senhor, pois, pela frivolidade de nosso saber, nos é significada a alteza do Vosso saber. 
23. Ah, Senhor leal e verdadeiro, pleno de todo saber! Como sou mesquinho, não agradeço mais a Vós os bens que tivésseis vontade de fazer nos tempos vindouros, e por não ter agradecido aqueles que me fizestes nos tempos passados, eu, Senhor, me sentencio, e rogo que Vós retireis ${ }^{38}$ meu ser deste século.

24. Isso porque, Senhor, é coisa muito injuriosa e má receber dons e benefícios de seu Criador e de seu Senhor, não lhe agradecer e ainda desconhecer Ele e Suas obras.

25. Senhor bom, Senhor generoso, Senhor louvado! Magnificência e liberalidade e honra existem em Vós e em Vosso saber, porque eu, Senhor, direi a todos os meus vizinhos e a todos os meus amigos, os quais duvidam de Vós, que vos temam, pois Vós sois tão sábio senhor e tão pleno de saber que nada que façam, digam ou pensem pode vos ser ocultado.

26. O mesmo direi, Senhor, à minha alma: que ela se guarde do que fará, o que pensará e por qual intenção fará o que fizer, pois tal poderá ser a obra ou a intenção que o sofrimento e a dor unirão e a dor multiplicará, ou tal poderá ser a obra e a intenção que a bênção e a bem-aventurada multiplicarão.

27. Contudo, Senhor, eu sou tâo pobre de virtudes e de entendimento que, sem a Vossa ajuda, dos homens e de mim mesmo, não poderia dizer ou desejar qualquer bem, caso náo me auxiliásseis com Vossa santa piedade.

28. Ah, Senhor Pai! Grandeza, medida e misericórdia sejam conhecidas em Vós e em Vosso saber, pois este sabe todas as falsidades, maldades, feiuras eu que cometi, disse, cogitei, pensei. Por isso, eu, Senhor, estou muito envergonhado diante do Vosso abençoado altar.

29. Pois, quando eu penso e recordo as faltas que cometi em minha juventude, e sei que Vós sabeis tudo, não é nenhuma maravilha que eu tenha vergonha e pavor de Vós, maiormente por não saber o que Vós fareis comigo, isto é, se me perdoareis ou me condenareis.

30. Se Vós, Senhor, sabeis todos os meus pecados e todos os meus erros, agrada-nos, Senhor, que me demonstrásseis a Vossa grande paciência, a Vossa grande misericórdia e a Vossa piedade, para que esse Vosso servo não se desespere de seu senhor Deus.

${ }^{38}$ No original, "delescat" (“delescar"?). Verbo inexistente no Dicionari català-valencià-balear. Trata-se, portanto, de uma proposta de tradução, conforme a ideia do item. 


\title{
Agradecimentos
}

Agradecemos à revisão técnica e leitura crítica do Prof. Evandro Santana Pereira, da E.E.E.F.M. "Pedreiras” (Pedra Azul, Domingos Martins - ES).

COSTA, Ricardo; SILVEIRA, Sidney. The prescience of God in St. Thomas Aquinas and in Lull's Book of Contemplation. Trans/Form/Ação, Marília, v. 38, n. 2, p. 9-34, Maio/ Ago., 2015.

\begin{abstract}
The purpose of this article is to analyze the philosophical conception of prescience in St. Thomas Aquinas in the Summa Theologica and Ramon Llull and the Book of Contemplation. To do so, we first discuss the Aristotelian-Thomist concept of science. We then present a translation of an extract from the Book of Contemplation as a documentary basis for the second part of the article.
\end{abstract}

KEYWORDS: science. prescience. medieval philosophy.

\section{REFERÊNCIAS}

AGOSTINHO. Confessiones. Madrid: Biblioteca de Autores Cristianos, 1998.

ARISTÓTELES. Metafísica. Ensaio introdutório, texto grego com tradução e comentário de Giovanni Reale. São Paulo: Loyola, 2005.

. Acerca del alma (De Anima). Apres., trad. e notas: Tomás Calvo Martínez. Madrid: Gredos, 2010.

BATALLA, Josep; FIDORA, Alexander. Introducció. In: LLULL, Ramon. Disputa entre la fe i l'enteniment. Introd., trad. i notes a cura Josep Batalla i Alexander Fidora. Turnhout: Brepols, 2011.

DETONI, Emerson. Santo Agostinho: fé, esperança e caridade. Mirabilia, n.11, p. 99-116, jun./dez. 2010.

FERRAZ, Pr. Luis Antônio. Teologia: a doutrina de Deus. In: Sola Scriptura TT. Online, 2014. Disponível em: <http://solascriptura-tt.org/TeologiaPropriaTrindade/ TeologiaPropria-LAFerraz.htm>. Acesso em: 06 jun. 2014.

LLULL, Ramon. Obres Essencials (OE). Barcelona: Editorial Selecta, 1957. v. 2. . Obres Essencials (OE). Barcelona: Editorial Selecta, 1960. v. 2.

. Disputa entre la fe i l'enteniment. Introd., trad. e notas de Josep Batalla i Alexander Fidora. Turnhout: Brepols, 2011 a. . El libro de los proverbios. Madrid: Miraguano, 2011b. 
COSTA, R.; SILVEIRA, S.

STRATHERN, Paul. Pitágoras y su teorema. Madrid: Siglo XXI de España, 1999.

TOMÁS DE AQUINO. Suma de Teología (Summa theologiae). Madrid: Biblioteca de Autores Cristianos, 1953.

. Suma contra os gentios. Tradução de D. Odilão Moura e D. Ludgero Jaspers; rev. de Luís Alberto De Boni. Porto Alegre: Escola Superior de Teologia São Lourenço de Brindes, 1990.

Questões disputadas sobre a alma. Tradução de Luiz Astorga. São Paulo: É Realizações, 2013. Ed. bilíngue.

TUCHMANN, Barbara W. A prática da história. Rio de Janeiro: José Olympio, 1991.

Recebido / Received: 01/03/2015

Aprovado / Approved: 10/04/2015 